\title{
子どもの栄養状態がその後の栄養状態・教育に与える長期的な影響
}

一カンボジア農村を事例として一

\author{
三輪 加奈 1$) *$
}

\section{Long-term Impact of Child Nutrition Status on Current Nutrition Status and Education: A Case Study from Rural Cambodia}

\author{
Kana Miwa ${ }^{1) *}$
}

The nutrition status in early childhood affects child's healthy development and acquisition of education and human capital, and health status and productivity in adulthood. The objective of this study is to explore the long-term impact of (childhood) nutrition status on the current BMI (Body Mass Index) and education of individuals, by focusing on rural Cambodia. From the estimation キーワード : 子どもの栄養, 教育, パネルデータ分析,

\section{1. はじめに}

子どもの健康・栄養を考学ることは，それがその 後の成長に大きな影響を与兄, 教育や保健といった 人的資本 (human capital) の形成・蓄積の基礎とな ることから非常に重要である. 特に, 開発途上国に おいて, 子どもの栄養不良は貧困と相互に関連して 抢り, 子どもの健康・栄養状態の改善や教育水準の 向上は, 将来の経済成長や持続的発展にとって，ま た, 開発の最終目標である貧困削減にとっても大き な意味をもっている。

幼少期の健康・栄養状態は, その後の健全な発育 や教育水準・成果 (学業成績など), さらには大人に なってからの健康状態や労働生産性（労働の質）な どにも影響を与えていることが，さまざまな研究で 指摘されている。 また，それらに関するパネルデー タ（長期データ）を用いた研究も蓄積されつつあり, results of longitudinal data analysis, I found that the past nutrition status, measured by height for age and weight for age $z$-scores, is positively associated with the current nutrition status. In addition, children who have had better nutrition are more likely to have a higher number of years of schooling.

\section{カンボジア}

その関連性がより明確となってきている.

将来の健康状態について，いくつかの研究をレ ビューした Reilly and Kelly（2011）は，多くの研究 を総合し, 幼少・青年期の過体重・肥満が成人期の 早死や罹病のリスクを高めらると指摘している. Alderman et al. (2006) は，ジンバブエ農村でのパネ ルデータを用いた分析により，5歳未満での年齢別 身長で測った栄養状態のその後の影響を検証し, 幼 少期の栄養状態の良さが青年期の身長の増加をもた らすといら結論を得ている。

Alderman et al.（2006）はまた，幼少期のよりよい 栄養状態が, より早い年齢での入学々就学年数の増 加をもたらすことも示している. 教育に関しては, 他にも, 幼少期のよりよい栄養・健康状態が, 就学 年齢や就学年数, 進学率, 留年しない可能性, 学業 達成度などに正の影響を与えていることが指摘され

\footnotetext{
1) 釧路公立大学経済学部; Faculty of Economics, Kushiro Public University of Economics

*E-mail:miwa@kushiro-pu.ac.jp (地域農林経済学会
} 
ている (Alderman et al., 2001; Alderman et al., 2009; Glewwe et al., 2001; Yamauchi, 2008 ら)．また，グア テマラでの長期データを用いて，乳幼児に対して栄 養価の高い補助食品を提供するといら介入の長期的 な影響を考察した Maluccio et al. (2009) は，それが 成人期でみた教育成果（就学年数と読解力，拉よび 非言語的認知能力）飞正の影響を与えていることを 指摘している.

他方で, Handa and Peterman（2007）は，南アフ リカでは幼少期の栄養状態が現在の教育に与兄る影 響はみられないと結論づけていて，すべての研究の 見解が必ずしも一致しているわけではない.

カンボジアを対象とした研究では，三輪（2012） が 2 期間のパネルデータを用いて, 現在の学年と学 年の遅孔の程度で測った教育指標に対して，その子 ぞもの過去（幼少期）の栄養状態のよさが正の影響 を与えていることを示している，しかしながら，現 在の栄養状態に対する過去のそれの影響については 考察されていない，また，栄養状態については長期 （慢性）の栄養不良を評価する年齢別身長だけの影響 を久て特り，体重については考慮されていない，

そこで, 本研究では開発途上国のひとつであるカ ンボジアの, 特に貧困問題が深刻な農村部での子ど もの栄養と教育に焦点をあて, カンボジア農村での 家計調査により収集した独自のパネルデータを用い て, 身長と体重からみた（過去の）子どもの栄養状 態と 7 年後のその子どもの栄養状態拈よび教育との 関連性について検証する.

カンボジアを事例とした子どもの栄養・健康と教 育に関する研究はそれ汪ど数がなく，また全国規模 でのそれに関するパネルデータは整備されていない. そこで, カンボジア平野部に位置し, カンボジアの 標準的な農村ともい光る本研究の調查地からのパネ ルデータを用いて，子どもの栄養状態の（異時点の） 栄養と教育への長期的な影響を検証し，その関係を 明らかにすることは, カンボジアの開発や貧困削減 の最重要課題とされる保健和よび教育分野の政策を 検討する際の基礎的情報として重要な意味をもつと いえる.

\section{2. 調査の概要}

本研究では, 2007 年と 2014 年にカンボジアの首
都プノンペンから南西に車で 1 時間半〜 2 時間ほど に位置する，コンポンスプー州とタケオ州の 4 村に おいて, 各村の住民台帳よりランダムに抽出した 164 世帯からのデータを用いる1.な报，その後の調査 で脱落があり， 2014 年飞調査できた（両年ともの データが整っている）のは 151 世帯である.

調査村の 4 村は，ともにカンボジアの平野部に位 置し，主な生業は稲作中心の農業で，その主な形態 は天水農業である (2007 年調査時で標本世帯の $73 \%$ が農家 $\left.{ }^{2}\right)$ 。ただし，村により水資源に違いがあるよ らで，雨季の稲作とあわせて二毛作を行っている世 帯（村）もあれば，水資源が乏しい（他より降水量 が少なく，ため池なぞも存在しない）村では，雨季 でも干ばつなどの被害を受けやすく，また乾季に作 物を栽培することが困難である．特に水資源の乏し い村では，農業以外の所得創出手段として「ほうき」 の生産・売買が盛んであったり，アイスクリームの 移動販売や資源回収，建築作業員など，非農業部門 で生計を立てている世帯も多くみられる。また, 2014 年調査時には調査村の近隣での縫製・縫靴工場の建 設・稼働もみられ，村に居住しながら工員として働 く世帯員も少なからずみられるよらになってきて いる.

標本世帯の概要を示した表 1 より，2014 年調査時 の平均世帯所得は 1 年間で約 2,892 ドル $(11,856,710$ リエル3) であり，これを 1 人あたりにすると約 700 ドルとなっている．2007 年と比べると世帯所得，1 人あたり世帯所得ともに約 3 倍増えている。 これは， 主に非農業所得の向上によるものと考兄られ，近隣 での縫製・縫靴工場での仕事や，世帯所得の向上を 背景とした調査村掞よびその周辺での家の新築・增 改築，工場建設などによる建設作業員や大工などの 非農業部門への就業機会が増加しているためと考兄 られる。

本稿では，パネルデータを用いて子どもの過去 （2007 年）の栄養状態が現時点（2014 年）の栄養状 態と教育に与える影響を検証するため，(できるだけ 多くの子ぞもについて検証すべく） 2007 年の調査時 に 15 歳以下で, 2014 年にも標本世帯の構成員であ るもの（215人）を対象に分析を行う。 
表 1 . 標本世帯の概要

\begin{tabular}{|c|c|c|}
\hline & 2007 年 & 2014 年 \\
\hline 標本世帯数 & 164 & 151 \\
\hline 世帯構成員数（人） & 4.6 & 4.3 \\
\hline 労働者数（人） & 2.4 & 2.6 \\
\hline 世帯主の年齢（歳） & 47.1 & 50.6 \\
\hline 世帯主の教育年数（年） & 4.1 & 4.9 \\
\hline 農地所有面積 1)（m²） & 8,649 & 8,911 \\
\hline 世帯所得（リエル/年） & $3,827,820$ & $11,856,710$ \\
\hline 農業所得比率（\%） & 33.5 & 30.3 \\
\hline 非農業所得比率（\%） & 42.4 & 51.1 \\
\hline 送金比率（\%） & 18.0 & 12.5 \\
\hline 1 人あたり世帯所得（リエル/年） & 918,028 & $2,873,267$ \\
\hline
\end{tabular}

出所）農村聞き取り調査より，筆者作成.

1）農地を所有している世帯のみの平均值.

\section{3. 実証分析}

（1）実証モデル

以下では，子どもの初期（1 期目）の栄養状態が, 現在（2 期目）の栄養状態と教育に与える影響につ いて考察するため, 現在の栄養と教育の決定関数を 次のように定式化する.

$Y_{i 2}=\beta_{0}+\beta_{1} \cdot H_{i 1}+\boldsymbol{\beta}_{2} \cdot \mathbf{X}_{i t}+\boldsymbol{\beta}_{3} \cdot \mathbf{X}_{h t}+\boldsymbol{\beta}_{4} \cdot \mathbf{V}_{h}+u_{i}$

被説明変数である $Y_{i 2}$ は，子ども $i$ の 2 期目 $(2014$ 年) での栄養・教育水準を示す。本稿では, 栄養状 態を測る指標として, 調査時に計測した身長と体重 から算出した BMI (Body Mass Index ${ }^{4}$ ) 用いるが, BMI の值そのものと, BMI 值により次のように分 類 ${ }^{5}$ したものを被説明変数とする.

$Y_{i 2}\left\{\begin{array}{l}=1 \text { if } \text { 低体重 (Underweight) } \\ =2 \text { if } \text { 普通体重 (Normal range) } \\ =3 \text { if } \text { 過体重/肥満 (Overweight/Obese) }\end{array}\right.$

なお，BMI 值については OLS で，BMI 分類につ いては多項ロジット・モデルにより推計をする. 教 育指標には, 教育年数（既に卒業や中退により学校 に通っていない場合には最終学年を, 在学中の場合 には現在の学年）を用い, トービット・モデルによ り推計を行ら 6 .

過去の栄養状態 $H_{i 1}$ については，長期（慢性）の 栄養不良を評価するのに適した指標といわれる「年 齢別身長 $z$ スコア」と, 短期（急性）の栄養不良を
評価するのに適した指標である「年齢別体重 $\mathrm{Z}$ スコ ア」の 2 指標を用いて，その影響を検証する 7 .

他の説明変数である $\mathrm{X}_{i t}$ は子どもの属性（性別, 年歯, 出生順位), $\mathrm{X}_{h t}$ は両親・世帯の属性（両親の 年齢・教育年数, 世帯主の性別・職業, 資産, 農地 所有面積）を示している。農地は，その所有面積が 広い活ど子どもが農作業を手伝らことが多くなると 考えられるため, 農地面積と子どもの年齢の交差項 も説明変数として加え, その影響を検証する。また, 子どもの栄養状態には生まれながらにもっている健 康の賦存量（health endowment）も影響していると 考えられるが，それは直接観察できないため，その 代理変数として両親の身長を，BMI に関する推計の 際の説明変数として用いることとする， $\mathrm{V}_{h}$ は世帯が 居住する村の属性（村ダミ一，， $\beta_{0} \sim \beta_{4}$ はパラメー タ， $u_{i}$ は攪乱項をそれぞれ示している.

本稿の分析対象の子どもは同一世帯内に複数いる 場合があり，その場合には同一世帯内の子どもの栄 養・教育の決定が，（1）式の推計に含まれる説明変 数以外のなんらかの共通因子の影響を受ける可能性 がある。この点を考慮するため，本稿の分析では同 一世帯の子どもを同一クラスタとみなし，同一クラ スタ内では誤差項は相関するといら仮定の下で標準 誤差を補正しらるクラスタロバスト標準誤差 （cluster-robust standard errors）を用いる．実際の推 計に用いた変数と基本統計量は, 表 2 の通りである.

\section{(2) 推定結果}

表 3 は過去の栄湌状態として年齢別身長 $\mathrm{z}$ スコア （HAZ）を，表 4 は年齢別体重 $\mathrm{z}$ スコア（WAZ）を用 いて，（1）式の子どもの栄養・教育の決定関数を推 計した結果をそれぞれ示している.

現在の BMI への過去の年齢別身長で測った栄湌 状態の影響を考察した OLSによる推計結果（表 3 (A) ) より，HAZの係数が正に有意となっており， 過去の栄養状態のよさが現在の体格に影響を与えて いることが示唆される. その他の変数として，子ど もの性別と年歯，世帯主が非農業部門に従事してい ることが，BMI に有意な影響を与えていることがわ かる.

BMI の值により低体重・普通体重・過体重の 3 つ のカテゴリーに分類し, その決定関数の多項ロジッ ト・モデルによる推計から得られた限界効果 
表 2 . 変数の定義と基本統計量

\begin{tabular}{|c|c|c|c|}
\hline 変数名 & 定義 & 平均 & 標準偏差 \\
\hline BMI & 子どもの BMI 值（2014 年） & 18.769 & 3.218 \\
\hline BMI 分類 & 子ぞもの BMI 分類（低体重 $=1$, 普通体重 $=2$, 過体重 $=3 ）$ & 1.777 & 0.595 \\
\hline 教育年数 & 子どもの教育年数/学年（年, 2014 年） & 7.619 & 3.208 \\
\hline $\mathrm{HAZ}$ & 初期の年齢別身長 z スコア（2007 年） & -2.367 & 1.304 \\
\hline WAZ & 初期の年齢別体重 $z$ スコア（2007 年） & -2.112 & 0.985 \\
\hline 子性別 & 子どもの性別（女览=1, 男児=0） & 0.488 & \\
\hline 子年齢 & 子どもの年齢（歳, 2007 年） & 9.352 & 3.890 \\
\hline 出生順位 & 子どもの出生順位 & 3.005 & 1.755 \\
\hline 母年齢 & 母親の年齢（歳，2007 年） & 37.524 & 7.119 \\
\hline 母教育 & 母親の教育年数（年） & 3.651 & 2.860 \\
\hline 母身長 & 母親の身長（cm） ～～～～～～～ & 151.986 & 5.303 \\
\hline 父年齢 & 父親の年齢（歳, 2007 年） & 38.553 & 7.776 \\
\hline 父教育 & 父親の教育年数（年） & 5.056 & 3.090 \\
\hline 父身長 & 父親の身長 (cm) & 162.715 & 6.508 \\
\hline 世帯主性別 & 世帯主の性別（女性=1，男性=0） & 0.149 & \\
\hline 世帯主職業 & 世帯主の職業（非農業部門に従事 $=1$, それ以外 $=0,2007$ 年） & 0.293 & \\
\hline 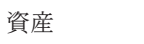 & 世帯の所有物的固定資産 1)（対数値，2007 年） & 15.827 & 0.947 \\
\hline 農地面積 & 世帯の農地所有面積（ha, 2007 年） & 0.799 & 0.558 \\
\hline 農地*年齢 & 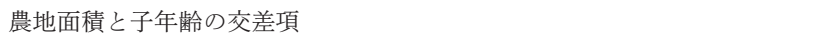 & 7.651 & 7.068 \\
\hline 村ダミ一 & 子ぞもの初期の栄養状態が相対的に良好な村をベースとする 3 の村ダミー & & \\
\hline
\end{tabular}

出所）農村聞き取り調査より，筆者作成.

1）物的固定資産には，農用資産と所有家畜，耐久消費財，貴金属おょび家屋（現在価値）が含まれる.

（marginal effects）を示したのが，表 3（B）である. これより，HAZの係数が低体重に対しては負に，普 通体重に対しては正に有意となっていることから, HAZ が改善することは低体重になる可能性を低める 一方，普通体重を維持することに効果があると考光 られる。

表 3 (C) は, トービット・モデルにより子どもの 教育年数の決定関数を推計した結果を示している. ここでも過去の栄養状態のよりよい子どもほど，教 育年数が長いことがわかり，栄養状態の正の影響が みられる。また，カンボジア農村では，母親の教育 年数よりも，父親の教育年数がその子どもの教育に 影響を与えていることが推定結果からわかる. さら に, 世帯の農地面積が負で, 農地面積と子どもの年 齢の交差項が正でそれぞれ有意となっている. この ことは，世帯が所有する農地面積が広いために，農 作業の手伝いをする必要などから教育年数に負の影 響を与える一方, 農地面積の広さ（つまりは農作物 の収穫量の多さ）が世帯所得の高さにつながり，農 業労働者の雇い入れや必要とあれば教育資金の借入 が容易にできることなどから，年齢の高い子どもで
あっても長く学校に通わせることが可能となるのて はないかと解釈できる 8 .

年齢別体重を過去の栄養状態の指標として用いた 推定結果では，年齢別身長の結果と同様に BMI 值に 対するWAZ の正に有意な影響が確認される（表 4 (A)). 表 4 (B) の BMI 分類の多項ロジット・モデ ルによる推計結果も，WAZ の值が大きい（栄養状態 がよりよい）ことが，低体重になる可能性を低める 一方で，普通体重となる確率を有意に高めることを 示している.

ここで，母親の教育年数の影響について，母教育 の係数は BMI 值の推計に括いていずれも負に有意と なっている．また，表 4 （B）より過体重となる確率 に対しても負の影響を与えていることがわかる. BMI に対する母親の教育年数の負の影響は，より教育を 受けた母親ほど，太りすぎが体に良くないことを理 解していたり，また（そしてそれゆえに）子どもの 食事の栄養バランスによく気を配っており，そのた めに子ぞもが肥満（過体重）になりにくいためでは ないかと推測される.

な抏，教育年数に対するWAZ の有意な影響はみ 
表 3. 年齢別身長のその後の栄養と教育への長期的影響

\begin{tabular}{|c|c|c|c|c|c|}
\hline \multirow{3}{*}{$\begin{array}{c}\text { モデル } \\
\text { 被説明変数 }\end{array}$} & \multirow{3}{*}{$\begin{array}{l}\text { (A) } \\
\text { OLS } \\
\text { BMI }\end{array}$} & \multicolumn{3}{|c|}{ (B) } & \multirow{3}{*}{$\begin{array}{c}\text { (C) } \\
\text { トービット } \\
\text { 教育年数 }\end{array}$} \\
\hline & & \multicolumn{3}{|c|}{ 多項ロジット（BMI 分類） } & \\
\hline & & 低体重 & 普通体重 & 過体重 & \\
\hline 説明変数 & 係数 1) & 限界効果 & 限界効果 & 限界効果 & 係数 \\
\hline HAZ & $\begin{array}{l}0.593^{* * *} \\
(0.177)\end{array}$ & $\begin{array}{c}-0.079^{* * *} \\
(0.029)\end{array}$ & $\begin{array}{l}0.075^{* * *} \\
(0.028)\end{array}$ & $\begin{array}{c}0.003 \\
(0.017)\end{array}$ & $\begin{array}{l}0.243^{* *} \\
(0.114)\end{array}$ \\
\hline 子性別 & $\begin{array}{r}-0.949 * \\
(0.480)\end{array}$ & $\begin{array}{c}0.103 \\
(0.074)\end{array}$ & $\begin{array}{r}-0.026 \\
(0.079)\end{array}$ & $\begin{array}{r}-0.076 \\
(0.047)\end{array}$ & $\begin{array}{c}0.212 \\
(0.276)\end{array}$ \\
\hline 子年齢 & $\begin{array}{l}0.450^{* *} \\
(0.147)\end{array}$ & $\begin{array}{c}-0.034^{*} \\
(0.019)\end{array}$ & $\begin{array}{c}0.031 \\
(0.020)\end{array}$ & $\begin{array}{c}0.003 \\
(0.013)\end{array}$ & $\begin{array}{l}0.332^{* * * *} \\
(0.081)\end{array}$ \\
\hline 出生順位 & $\begin{array}{c}-0.127 \\
(0.206)\end{array}$ & $\begin{array}{c}-0.011 \\
(0.033)\end{array}$ & $\begin{array}{c}0.014 \\
(0.038)\end{array}$ & $\begin{array}{c}-0.003 \\
(0.020)\end{array}$ & $\begin{array}{c}0.006 \\
(0.129)\end{array}$ \\
\hline 母年齢 & $\begin{array}{c}0.105 \\
(0.085)\end{array}$ & $\begin{array}{r}-0.005 \\
(0.015)\end{array}$ & $\begin{array}{c}-0.0005 \\
(0.015)\end{array}$ & $\begin{array}{c}0.006 \\
(0.009)\end{array}$ & $\begin{array}{c}0.048 \\
(0.052)\end{array}$ \\
\hline 母教育 & $\begin{array}{c}-0.199 * \\
(0.106)\end{array}$ & $\begin{array}{c}-0.002 \\
(0.016)\end{array}$ & $\begin{array}{c}0.024 \\
(0.018)\end{array}$ & $\begin{array}{c}-0.022 \\
(0.014)\end{array}$ & $\begin{array}{c}0.029 \\
(0.067)\end{array}$ \\
\hline 母身長 & $\begin{array}{c}0.023 \\
(0.043)\end{array}$ & $\begin{array}{c}0.002 \\
(0.007)\end{array}$ & $\begin{array}{r}-0.002 \\
(0.008)\end{array}$ & $\begin{array}{c}0.0005 \\
(0.005)\end{array}$ & \\
\hline 父年齢 & $\begin{array}{r}-0.066 \\
(0.062)\end{array}$ & $\begin{array}{c}0.016 \\
(0.012)\end{array}$ & $\begin{array}{r}-0.006 \\
(0.012)\end{array}$ & $\begin{array}{r}-0.010 \\
(0.008)\end{array}$ & $\begin{array}{c}-0.033 \\
(0.041)\end{array}$ \\
\hline 父教育 & $\begin{array}{r}-0.014 \\
(0.075)\end{array}$ & $\begin{array}{c}0.007 \\
(0.013)\end{array}$ & $\begin{array}{r}-0.008 \\
(0.014)\end{array}$ & $\begin{array}{c}0.001 \\
(0.007)\end{array}$ & $\begin{array}{l}0.168^{* * *} \\
(0.055)\end{array}$ \\
\hline 父身長 & $\begin{array}{c}0.016 \\
(0.043)\end{array}$ & $\begin{array}{c}0.001 \\
(0.006)\end{array}$ & $\begin{array}{r}-0.005 \\
(0.008)\end{array}$ & $\begin{array}{c}0.004 \\
(0.007)\end{array}$ & \\
\hline 世帯主性別 & $\begin{array}{c}-0.245 \\
(0.622)\end{array}$ & $\begin{array}{c}0.098 \\
(0.178)\end{array}$ & $\begin{array}{r}-0.066 \\
(0.205)\end{array}$ & $\begin{array}{c}-0.032 \\
(0.074)\end{array}$ & $\begin{array}{c}-0.696^{*} \\
(0.367)\end{array}$ \\
\hline 世帯主職業 & $\begin{array}{c}1.049 * \\
(0.598)\end{array}$ & $\begin{array}{r}-0.045 \\
(0.085)\end{array}$ & $\begin{array}{c}0.038 \\
(0.091)\end{array}$ & $\begin{array}{c}0.007 \\
(0.044)\end{array}$ & $\begin{array}{c}0.233 \\
(0.368)\end{array}$ \\
\hline 資産 & $\begin{array}{c}0.325 \\
(0.319)\end{array}$ & $\begin{array}{c}0.052 \\
(0.047)\end{array}$ & $\begin{array}{r}-0.057 \\
(0.053)\end{array}$ & $\begin{array}{c}0.005 \\
(0.036)\end{array}$ & $\begin{array}{c}0.272 \\
(0.165)\end{array}$ \\
\hline 農地面積 & $\begin{array}{c}0.080 \\
(1.122)\end{array}$ & $\begin{array}{c}-0.038 \\
(0.175)\end{array}$ & $\begin{array}{c}-0.054 \\
(0.198)\end{array}$ & $\begin{array}{c}0.092 \\
(0.122)\end{array}$ & $\begin{array}{c}-1.796^{* * * *} \\
(0.613)\end{array}$ \\
\hline 農地*年齢 & $\begin{array}{c}-0.013 \\
(0.103) \\
\end{array}$ & $\begin{array}{c}-0.004 \\
(0.016)\end{array}$ & $\begin{array}{c}0.018 \\
(0.018) \\
\end{array}$ & $\begin{array}{c}-0.014 \\
(0.014)\end{array}$ & $\begin{array}{l}0.224^{* * *} \\
(0.069)\end{array}$ \\
\hline $\begin{array}{l}\text { 標本数 } \\
\text { 決定係数 2) }\end{array}$ & $\begin{array}{r}160 \\
0.404\end{array}$ & $\begin{array}{r}160 \\
0.156\end{array}$ & & & $\begin{array}{r}194 \\
0.217\end{array}$ \\
\hline
\end{tabular}

1）*は $10 \% ， * *$ は $5 \%$ ，***は 1\%で統計的に有意. 推計には切片と村ダミーも含み，括弧内はロバストクラスタ標準誤差を 示す.

2) OLS は自由度修正済み $\mathrm{R}^{2}$ ，多項ロジットとトービット・モデルはPseudo $\mathrm{R}^{2}$ をそれぞれ示す。

られなかった（表 4 (C)).

ここで，教育への影響について，教育年数（現在 の学年）そのものよりも, 年齢に応じた教育年数で あるか（年齢に即した学年に在籍しているか）の注 らがより重要である可能性がある。 そこで，年齢に 応じた相対的な教育年数（SAGE）を用いて再推計 を試みることにする ${ }^{9}$. 具体的には,
$S A G E=$ 年歯令 $-E-$ 現在の学年

を計算し，それを被説明変数とする（Eは正規の初 等教育への入学年齿).なお，すでに学校に通ってい ない者については，最終学年を用いて SAGE を算出 している。

SAGE を被説明変数として, OLS で推計した結果 
表 4. 年齢別体重のその後の栄養と教育への長期的影響

\begin{tabular}{|c|c|c|c|c|c|}
\hline \multirow{3}{*}{$\begin{array}{c}\text { モデル } \\
\text { 被説明変数 }\end{array}$} & \multirow{3}{*}{$\begin{array}{c}\text { (A) } \\
\text { OLS } \\
\text { BMI }\end{array}$} & \multicolumn{3}{|c|}{ (B) } & \multirow{3}{*}{$\begin{array}{c}\text { (C) } \\
\text { トービット } \\
\text { 教育年数 }\end{array}$} \\
\hline & & \multicolumn{3}{|c|}{ 多項ロジット（BMI 分類） } & \\
\hline & & 低体重 & 普通体重 & 過体重 & \\
\hline 説明変数 & 係数 1) & 限界効果 & 限界効果 & 限界効果 & 係数 \\
\hline WAZ & $\begin{array}{l}0.324^{* * * *} \\
(0.238)\end{array}$ & $\begin{array}{c}-0.144^{* * *} \\
(0.035)\end{array}$ & $\begin{array}{l}0.118^{* * *} \\
(0.038)\end{array}$ & $\begin{array}{c}0.024 \\
(0.029)\end{array}$ & $\begin{array}{c}0.197 \\
(0.147)\end{array}$ \\
\hline 子性別 & $\begin{array}{r}-0.876^{*} \\
(0.487)\end{array}$ & $\begin{array}{c}0.089 \\
(0.076)\end{array}$ & $\begin{array}{c}0.002 \\
(0.080)\end{array}$ & $\begin{array}{c}-0.091^{*} \\
(0.048)\end{array}$ & $\begin{array}{c}0.216 \\
(0.273)\end{array}$ \\
\hline 子年齢 & $\begin{array}{l}0.431 * * * \\
(0.141)\end{array}$ & $\begin{array}{c}-0.026 \\
(0.017)\end{array}$ & $\begin{array}{c}0.017 \\
(0.020)\end{array}$ & $\begin{array}{c}0.009 \\
(0.012)\end{array}$ & $\begin{array}{l}0.318^{* * * *} \\
(0.076)\end{array}$ \\
\hline 出生順位 & $\begin{array}{c}-0.081 \\
(0.210)\end{array}$ & $\begin{array}{c}-0.024 \\
(0.034)\end{array}$ & $\begin{array}{c}0.017 \\
(0.039)\end{array}$ & $\begin{array}{c}0.007 \\
(0.022)\end{array}$ & $\begin{array}{c}-0.023 \\
(0.121)\end{array}$ \\
\hline 母年齢 & $\begin{array}{c}0.088 \\
(0.084)\end{array}$ & $\begin{array}{r}-0.002 \\
(0.014)\end{array}$ & $\begin{array}{c}-0.00001 \\
(0.015)\end{array}$ & $\begin{array}{c}0.002 \\
(0.007)\end{array}$ & $\begin{array}{c}0.049 \\
(0.049)\end{array}$ \\
\hline 母教育 & $\begin{array}{c}-0.208 * \\
(0.108)\end{array}$ & $\begin{array}{c}0.002 \\
(0.017)\end{array}$ & $\begin{array}{c}0.020 \\
(0.018)\end{array}$ & $\begin{array}{c}-0.022^{*} \\
(0.012)\end{array}$ & $\begin{array}{c}0.021 \\
(0.065)\end{array}$ \\
\hline 母身長 & $\begin{array}{c}0.009 \\
(0.043)\end{array}$ & $\begin{array}{c}0.004 \\
(0.007)\end{array}$ & $\begin{array}{r}-0.005 \\
(0.008)\end{array}$ & $\begin{array}{c}0.001 \\
(0.005)\end{array}$ & \\
\hline 父年齢 & $\begin{array}{r}-0.067 \\
(0.061)\end{array}$ & $\begin{array}{c}0.016 \\
(0.011)\end{array}$ & $\begin{array}{r}-0.006 \\
(0.013)\end{array}$ & $\begin{array}{r}-0.010 \\
(0.008)\end{array}$ & $\begin{array}{r}-0.027 \\
(0.041)\end{array}$ \\
\hline 父教育 & $\begin{array}{r}-0.002 \\
(0.077)\end{array}$ & $\begin{array}{c}0.007 \\
(0.014)\end{array}$ & $\begin{array}{r}-0.006 \\
(0.015)\end{array}$ & $\begin{array}{r}-0.001 \\
(0.007)\end{array}$ & $\begin{array}{l}0.175^{* * *} \\
(0.056)\end{array}$ \\
\hline 父身長 & $\begin{array}{c}0.012 \\
(0.046)\end{array}$ & $\begin{array}{c}0.001 \\
(0.007)\end{array}$ & $\begin{array}{r}-0.004 \\
(0.008)\end{array}$ & $\begin{array}{c}0.003 \\
(0.007)\end{array}$ & \\
\hline 世帯主性別 & $\begin{array}{c}0.213 \\
(0.638)\end{array}$ & $\begin{array}{c}0.033 \\
(0.204)\end{array}$ & $\begin{array}{c}0.005 \\
(0.233)\end{array}$ & $\begin{array}{r}-0.038 \\
(0.076)\end{array}$ & $\begin{array}{c}-0.512 \\
(0.361)\end{array}$ \\
\hline 世帯主職業 & $\begin{array}{c}0.919 \\
(0.617)\end{array}$ & $\begin{array}{r}-0.037 \\
(0.091)\end{array}$ & $\begin{array}{c}0.032 \\
(0.098)\end{array}$ & $\begin{array}{c}0.005 \\
(0.048)\end{array}$ & $\begin{array}{c}0.212 \\
(0.369)\end{array}$ \\
\hline 資産 & $\begin{array}{c}0.344 \\
(0.327)\end{array}$ & $\begin{array}{c}0.039 \\
(0.046)\end{array}$ & $\begin{array}{r}-0.045 \\
(0.056)\end{array}$ & $\begin{array}{c}0.006 \\
(0.039)\end{array}$ & $\begin{array}{c}0.283^{*} \\
(0.166)\end{array}$ \\
\hline 農地面積 & $\begin{array}{c}0.223 \\
(1.026)\end{array}$ & $\begin{array}{c}-0.0002 \\
(0.170)\end{array}$ & $\begin{array}{r}-0.147 \\
(0.197)\end{array}$ & $\begin{array}{c}0.147 \\
(0.097)\end{array}$ & $\begin{array}{c}-1.868^{* * * *} \\
(0.543)\end{array}$ \\
\hline 農地*年齢 & $\begin{array}{c}-0.002 \\
(0.094)\end{array}$ & $\begin{array}{r}-0.011 \\
(0.015)\end{array}$ & $\begin{array}{c}0.032 * \\
(0.018) \\
\end{array}$ & $\begin{array}{c}-0.021^{*} \\
(0.011)\end{array}$ & $\begin{array}{l}0.235^{* * *} \\
(0.063)\end{array}$ \\
\hline $\begin{array}{l}\text { 標本数 } \\
\text { 決定係数 2) }\end{array}$ & $\begin{array}{r}162 \\
0.397\end{array}$ & $\begin{array}{r}162 \\
0.175\end{array}$ & & & $\begin{array}{r}196 \\
0.216\end{array}$ \\
\hline
\end{tabular}

1）*は $10 \% ， * *$ は $5 \%$ ，***は 1\%で統計的に有意. 推計には切片と村ダミーも含み，括弧内はロバストクラスタ標準誤差を 示す.

2) OLS は自由度修正済み $\mathrm{R}^{2}$ ，多項ロジットとトービット・モデルはPseudo $\mathrm{R}^{2}$ をそれぞれ示す。

を示したのが表 5 である。これより, 過去の栄養状 態について，HAZ の係数のみが負で有意となってい る. SAGE は数值が低いほど学年の遅れが少ないと いうことを意味する指標であるため，負で有意とい らことは, 過去の慢性の栄養状態がよい子ぞもほど, その年齢に対しての正規の学年に在籍する可能性が 高いということを意味し，教育年数の分析結果とも
整合的な結果となっている。 その他の変数について は，教育年数と㟫涪同様の結果が得られている.

\section{4. おわりに}

本稿では，過去の子ぞもの栄養状態が現在（その 後）の栄養状態扣よび教育に与える影響について, カンボジア農村からの 2 期間のパネルデータを用い 
表 5. 相対的な教育年数への長期的影響（OLS）

\begin{tabular}{|c|c|c|c|c|c|c|}
\hline 被説明変数 & \multicolumn{6}{|c|}{ SAGE } \\
\hline 説明変数 & \multicolumn{3}{|c|}{ 係数 ${ }^{1)}$} & \multicolumn{3}{|c|}{ 係数 } \\
\hline HAZ & -0.242 & $(0.119)$ & $* *$ & & & \\
\hline WAZ & & & & -0.198 & $(0.153)$ & \\
\hline 子性別 & -0.215 & $(0.287)$ & & -0.219 & $(0.284)$ & \\
\hline 子年齢 & 0.666 & $(0.083)$ & $* * *$ & 0.680 & $(0.078)$ & $* * *$ \\
\hline 出生順位 & -0.005 & $(0.134)$ & & 0.024 & $(0.126)$ & \\
\hline 母年齢 & -0.049 & $(0.054)$ & & -0.049 & $(0.052)$ & \\
\hline 母教育 & -0.029 & $(0.070)$ & & -0.021 & $(0.068)$ & \\
\hline 父年齢 & -0.167 & $(0.057)$ & & 0.027 & $(0.043)$ & \\
\hline 父教育 & -0.167 & $(0.057)$ & $* * *$ & -0.175 & $(0.058)$ & $* * *$ \\
\hline 世帯主性別 & 0.695 & $(0.383)$ & $*$ & 0.510 & $(0.376)$ & $* *$ \\
\hline 世帯主職業 & -0.240 & $(0.380)$ & & -0.219 & $(0.381)$ & \\
\hline 資産 & -0.271 & $(0.171)$ & & -0.282 & $(0.173)$ & \\
\hline 農地面積 & 1.783 & $(0.633)$ & $* * *$ & 1.857 & $(0.561)$ & $* * *$ \\
\hline 農地*年齢 & -0.222 & $(0.071)$ & $* * *$ & -0.234 & $(0.065)$ & $* * *$ \\
\hline 標本数 & & 194 & & & 196 & \\
\hline 決定係数 & & 0.619 & & & 0.623 & \\
\hline
\end{tabular}

1）*は $10 \%$ ，**は $5 \%$ ，***は 1\%で統計的に有意. 推計に は切片と村ダミーも含み, 括弧内はロバストクラスタ標準 誤差を示す。

て検証を行った。 その分析結果は，カンボジア農村 に居住する子どもの現在の栄養状態と教育に対して, その子どもの過去（幼少期）の栄養状態のよさが総 じて正の影響を与えていることを示唆している.た だし，教育に対しては HAZ のみが有意な効果を示し ていることから，慢性的に栄養状態がよい子ども流 ぞ学校に通い続けることができる, もしくは学年の 遅れが少なく，問題なく進級ができていると推測さ れる。

三輪（2012）でも，子ぞもの教育に対する HAZで 測った過去の栄養状態の正の影響が指摘されている. 本稿の分析結果も同様ではあるものの, 本稿の方が より分析対象期間が長く, WAZ の影響も検証してい るといら違いがあり, また, 父親の教育年数の長さ と世帯の農地所有面積の広さが教育に有意な影響を 与光るといら新たな知見も提示している. 加えて, 三輪（2012）では検証されていない, 現在の栄養状 態に対する過去の栄養状態の影響も考察し, その関 係を実証的に示したといら点で本研究は意義がある といえる.
本稿の実証結果を踏まえ, カンボジアに扔いて人 的資本としての栄養扣よび教育を蓄積し, 貧困削減 や将来の持続可能な発展を実現するためには，就学 年齢あるいは就学前年齢の子どもの栄養状態を改善 させるよらな政策がまずは重要となるだろら。併せ て, 初等教育への就学や学校・クラスでのパフォー マンスをより向上させるような政策を実施すること で，教育水準のより一層の改善に繋がるものと期待 される。また，親（特に父親）の教育年数が子ぞも の教育に有意な影響を与えていること，加えて，親 の教育の子どもの栄養に対する影響も指摘されてい ることから，子どもの教育水準の改善はその子ども のみならず, 将来（次世代）の子どもの栄養状態の 改善・教育の向上といら好循環の形成をもたらすも のと考光られる。それにより，人的資本のより多く の蓄積と, 貧困家計が貧困の罠から抜け出すことで 貧困の緩和がもたらされる可能性があることが示唆 される.

具体的な政策としては，栄養と教育が互いにとっ て重要な要素であることから，その関係，保健分野 と教育分野の関係をより強化することが重要である. そのために，カンボジア農村で広く実施されている 子どもに対する学校給食プログラムや微量栄養素 (micronutrients) の提供, 学校での保健衛生教育, および親（成人）に対する保健衛生や栄養，母子保 健なぞに関するへルス・プログラムなぞをより効率 的，かつ持続的に実施していくことが求められるた 万ら.

な报，本稿の分析には以下のよらな不十分の点も 残されている．本稿では，(主にサンプルサイズの問 題から） 1 期目に 15 歳以下の子ぞもを対象として分 析を行ったが，より幼少の時期の健康・栄養状態が その後に影響を与兄るとされていることから，5歳 未満児などに限った分析が必要であると考方る。ま た，教育年数だけでなく，成績や試験の点数などの 学校でのパフォーマンスも重要と考光られるため, それらのデータを用いた分析についても，今後に残 された課題である。

さらに，カンボジアでは経済成長が進んでおり， 農村部でもその影響を受け，これまでの農業中心の 生活とは異なる新しいライフスタイルが確立してい くことが予想される，そのような変化が子どもの人 
的資本の形成・蓄積にもたらす影響についても，注 意深く観察していく必要があるだろら。

\section{注}

12007 年の調査は日本学術振興会の科学研究費・基盤 (C)（課 題番号 : 19580251), 2014 年のそれは同・基盤（B）（課題番 号：25301025）和よび公益財団法人二十一世紀文化記念財団 の学術奨励金の助成により実施したものである.

2 世帯主の主な職業が「農業」の割合で，兼業農家も含めると その割合は $94 \%$ でる.

3「リエル」はカンボジアの通貨で, 1USドル $=4,100$ リエル (2018 年時点).な拈, 世帯所得には農作物等の生産物の自家 消費分 (の貨幣価值)，抒よび出稼ぎをしている家族からの 仕送り含含。

${ }^{4} \mathrm{BMI}$ は身長と体重の関係から肥満の程度を示寸指数で,「体 重 $(\mathrm{kg}) \div$ 身長 $(\mathrm{m}) \div$ 身長 $(\mathrm{m}) 」$ により算出される. 過去 の栄養状態を測る指標として用いる年齢別身長抢よび年齢別 体重は 20 歳までしか成長標準值が示されていないが，BMI については年齢を問わず使用することができるため, 2014 年 のデータで 20 歳以上も含む本稿の分析では栄養状態の指標 としてBMI を用いる.

5 世界保健機関（WHO）の基準により，0〜19 歳については, 年齢別 BMI（BMI for age）のグロース・チャートに照らし て, 標準体重の-1SD 未満を低体重, $-1 \mathrm{SD} \sim 1 \mathrm{SD}$ 未満を標 準体重, $1 \mathrm{SD}$ 以上を過体重としている. 20 歳以上について は，こちらも WHO の基準により, BMI 值が 18.5 未満を低体 重, $18.5 \sim 25$ 未満を普通体重, 25 以上を過体重と分類して いる.

6 トービット・モデルを用いるのは, 教育年数がゼロ（教育を まったく受けていない）のサンプルも含むためである。

7 年齢別身長/体重の指標は, 同じ性別・年齢のグループと比較 してその子どもの身長/体重がぞの程度であるかを示す指標で ある. WHO は，これらの指標を国際的な成長基準值に比例 させて， $z$ スコアにより表すことを推奨している. なお，本 稿の分析では先行研究を参考に, $\mathrm{z}$ スコアが -6 から 6 の間の 子どものみを分析の対象とする（ $\mathrm{z}$ スコアが-6より小さいあ るいは 6 より大きい場合には異常值とみなし, 年齢か身長・ 体重の計測などデータに何らかの不備があると考える).

8 ただしこの点については, データ制約上の問題から十分な根 拠を示すことができないため，今後さらなる検証が必要である.

${ }^{9} \mathrm{SAGE}$ の算出方法等については, Miwa et al. (2010) を参考 にしている.な拈, SAGEを用いても年齢に対して教育年数 が短いことが，入学遅延（正規の初等教育入学年齢よりも遅 れての入学) によるものなのか, 留年によるものなのかは区
別できない点に留意が必要である.

\section{引用文献}

三輪加奈（2012）「カンボジア農村に㧺ける子どもの健康と教 育一パネルデータによる実証分析」『農業経済研究』別冊 2012 年度日本農業経済学会論文集，379-386

Alderman, H., J. R. Behrman, V. Lavy, and R. Menon (2001) Child Health and School Enrolment: A Longitudinal Analysis, Journal of Human Resources 36(1): 185-169. https:// www.jstor.org/stable/3069675.

Alderman, H., J. Hoddinott, and B. Kinsey (2006) Long Term Consequences of Early Childhood Malnutrition, Oxford Economic Papers 58(3): 450-474. https://doi.org/10.1093/oep/ gp1008.

Alderman, H., H. Hoogeveen, and M. Rossi (2009) Preschool Nutrition and Subsequent Schooling Attainment: Longitudinal Evidence from Tanzania, Economic Development and Cultural Change 57(2): 239 - 260. https://www.jstor.org/stable/ $10.1086 / 592875$.

Glewwe, P., H. G. Jocoby, and E. M. King (2001) Early Childhood Nutrition and Academic Achievement: A Longitudinal Analysis, Journal of Public Economics 81(3): 345-368. https:// doi.org/10.1016/S0047-2727(00)00118-3.

Handa, S. and A. Peterman (2007) Child Health and School Enrollment: A Replication, Journal of Human Resources 42(4): 863-880. https://doi.org/10.3368/jhr.XLII.4.863.

Maluccio, J. A., J. Hoddinott, J. R. Behrman, R. Martorell, A. R. Quisumbing, and A. D. Stein (2009) The Impact of Improving Nutrition during Early Childhood on Education among Guatemalan Adults, Economic Journal 119: 734-763. https:// doi.org/10.1111/j.1468-0297.2009.02220.x.

Miwa, K., P. Han, and S. Fukui (2010) Dose Child Labor Have a Negative Impact on Child Education and Health? A Case Study in Rural Cambodia, Oxford Development Studies 38(3): 357-382. https://doi.org/10.1080/13600818.2010.505682.

Reilly, J. J. and J. Kelly (2011) Long-term Impact of Overweight and Obesity in Childhood and Adolescence on Morbidity and Premature Mortality in Adulthood: Systematic Review, International Journal of Obesity 35: 891-898. https://doi.org/ 10.1038/ijo.2010.222.

Yamauchi, F. (2008) Early Childhood Nutrition, Schooling, and Sibling Inequality in a Dynamic Context: Evidence from South Africa, Economic Development and Cultural Change 56(3): 687-682. https://www.jstor.org/stable/10.1086/533542. 